\title{
INFLUENCE OF NITRATE AND PHOSPHATE ON THE DISTRIBUTION AND ABUNDANCE OF RIPARIAN VEGETATION IN YOGYAKARTA CITY (Pengaruh Nitrat dan Fosfat pada Distribusi dan Kelimpahan Vegetasi Riparian Kota Yogyakarta)
}

\author{
Suwarno Hadisusanto*, Dwinda Mariska Putri, Raditia Nugraha, Muhammad Rifqi, Qisti \\ Fauziyah, Riska Putri Asmawati, Annisa Mawarni, Firda Nabila Nur Azizah, Dinda Ayu \\ Islami, dan Fitria Ratna Pratiwi \\ Laboratory of Ecology and Conservation, Faculty of Biology, Universitas Gadjah Mada, \\ Sekip Utara Yogyakarta 55281.
}

*Corresponding author. Tel: 08562937358. Email: hadisusantosuwarno@gmail.com.

Diterima: 4 Desember 2018

Disetujui: 4 Agustus 2019

\begin{abstract}
Abstrak
City of Yogyakarta has three major streams, they are Winongo, Code and Gajahwong. These urban stream accept high input of nutrients throughout the year. Nutrients are in form of organic and non organic matters originated from domestic waste, factory waste, and hospital waste. Riparian vegetation directly respond to stream ecosystem changes. This research aim to learn distribution and abundance of riparian vegetation in Winongo, Code, and Gajahwong, number of species presence in each sampling site, physic-chemical parameters including air and soil temperatures, air and soil humidity, soil $\mathrm{pH}$, light intensity, and $\mathrm{NO}_{3}{ }^{-}$and $\mathrm{PO}_{4}{ }^{3-}$ in water and riparian soil. In each station, samples were taken using 2x0.5 m plot with 10 replications in floodplain. There are three stations in each stream. Data collected was species number and names. Growth-form grass dominated in all stations. In Winongo the grass density are 1582 ind $/ 10 \mathrm{~m}^{2}$ (70\%), Code 1697 ind $/ 10 \mathrm{~m}^{2}(81 \%)$ and Gajahwong 1432 ind $/ 10 \mathrm{~m}^{2}(70 \%)$. The most abundant grass were Paspalum sp. in Winongo they were 764 ind $/ 10 \mathrm{~m}^{2}$ and in Gajahwong $1103 \mathrm{ind} / 10 \mathrm{~m}^{2}$. While Code was dominated by Panicum sp. they were 735 ind $/ 10 \mathrm{~m}^{2}$. Grass were quickly respond to high nutrient availability. High concentration of $\mathrm{NO}_{3}{ }^{-}$and $\mathrm{PO}_{4}{ }^{3-}$ trigger grass domination. Grass were known for their nutrient fixing behavior, therefore when Grass were most abundant, nutrient concentration decreased in each sampling station.
\end{abstract}

Kata kunci: Grass; Nitrate; Paspalum; Riparian; Phosphate.

\begin{abstract}
Kota Yogyakarta memiliki tiga sungai utama, yaitu sungai Winongo, Code dan Gajahwong. Sungai perkotaan ini membawa nutrien yang tinggi sepanjang tahun. Nutrien berupa bahan organik dan non organik ini berasal dari limbah domestik, limbah pabrik, dan limbah rumah sakit. Vegetasi riparian secara langsung merespon perubahan ekosistem sungai. Penelitian ini bertujuan untuk mempelajari sebaran dan kelimpahan vegetasi riparian di sungai Winongo, Code, dan Gajahwong, jumlah keberadaan spesies di setiap lokasi pengambilan sampel, parameter fisika-kimiawi

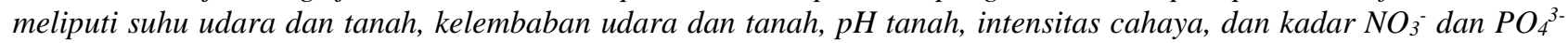
di air dan tanah riparian. Di setiap stasiun diambil sampel dengan menggunakan plot 2x0,5 m dengan 10 ulangan di dataran banjir. Ada tiga stasiun di setiap aliran. Data yang dikumpulkan adalah nomor dan nama spesies. Rerumputan berbentuk tumbuh mendominasi di semua stasiun. Di Winongo kerapatan rumput adalah 1582 ind / 10m² (70\%), Code 1697 ind / 10m² (81\%) dan Gajahwong 1432 ind / 10m² (70\%). Rerumputan yang paling melimpah adalah Paspalum sp. di Winongo seluas 764 ind / 10m² dan di Gajahwong 1103 ind / 10m2. Sedangkan Code didominasi oleh Panicum sp. mereka 735 ind $/ 10 \mathrm{~m}^{2}$. Rerumputan dengan cepat merespon ketersediaan hara yang tinggi. Konsentrasi $\mathrm{NO}_{3}{ }^{-}$dan $\mathrm{PO}_{4}{ }^{3-}$ yang tinggi memicu dominasi rumput. Rerumputan dikenal karena perilaku pengikat hara, oleh karena itu pada saat rumput paling melimpah, konsentrasi hara menurun di setiap stasiun pengambilan sampel.
\end{abstract}

Keywords: rumput; nitrat, Paspalum; riparian; fosfat.

\section{INTRODUCTION}

Riparian environments are ecotone zone. These zone are transitional zone that links between terrestrial and aquatic ecosystems. Riparian zonation is not easy to describe. For some area, the differences between zones are not distinct. Riparian zonation concept is integrated from many aspects such as physical factors that formed valley landscape. Riparian zone often washed away by water flow, thus vegetation remain wet (Gregory et al. 2012). In urban area, riparian vegetation role in regulating runoff water from higher land into river, as buffer for floodplain, pollution reduction, and source of energy for river organisms (Behren et al. 2013). 
The main factor that causing river pollution in urban area is the large number of surface runoff from higher land into the river. In urban area, runoff brings in large nutrient load because lack of trees to absorb the nutrient (Allan 2004). Research in Georgia Pieldmont showed that riparian vegetation has a strong relation with watershed condition. Landscape conditions also play role in determining the existence of species in riparian area (Burton et al. 2008). Therefore, high nutrient supply can also reduce the number of species presence. Riparian vegetation respond to high nutrient load shown by domination of some species that inhibit other species growth (Allan 2004). Proportion and diversity of watersheds play major role on stream water quality. Urban area only left small proportion of catchment area, leave only small part for vegetation to grow. Larger catchment area allows nutrient reduce and material losses then improve water quality (Clement et al. 2017)

Study about relation between riparian vegetation and nutrient are broadly learnt. Each site showed different characteristic as different landscape affected by different anthropogenic activity (Connoly et al. 2016). Riparian vegetation can reduce urban pollution flow into the river by absorbing some nutrient. When riparian vegetation is absent, high nutrient occur in river indicated by algae blooming (Sabater 2000). Riparian vegetation absorption is limited, but large number of riparian vegetation can hold large amount of nutrient (Haycock dan Pinay 1993). Riparian zone length, width, and vegetation type, have critical roles in enabling forest fragments to reset negative effect of agriculture. Loss of some diversity in catchment areas reducing their role instabilizing stream waterfront pollution (Harding 2006).

City of Yogyakarta has three main streams. They are Winongo, Code dan Gajahwong. These streams are classified as urban streams. They accept high input of nutrient daily. Nutrient input can flow as organic matters or inorganic matters come from domestic, factory and hospital waste. Riparian vegetation immediately respond to stream condition. These three streams situated in the center of Yogyakarta where terrestrial vegetation are rarely found.

The purposes of this research are studying distribution and abundance of riparian vegetation in Winongo, Code and Gajahwong, number of species presence in each sampling site, physic-chemical factors includes water and soil temperature, soil $\mathrm{pH}$, streams depth, current velocity, also $\mathrm{N}$ and $\mathrm{P}$ available in soil and water. The data can be used as a long-term monitoring for stream's health in City of Yogyakarta.

\section{METHODS}

\section{Study Sites}

This study was conducted on three separate streams in the middle city of Yogyakarta (Fig 1). The streams were Winongo, Code, and Gajahwong. These streams are small stream ecosystem that each stream has $7.06 \mathrm{~km}, 8.73 \mathrm{~km}$, and 6.03 in length. These streams uptake huge amount of nutrient. Sources of nutrient are from domestic, industrial, and hospital waste. Because of that, only small amount of riparian vegetation were found in the watershed.

\section{Sample Collection}

Samples were collected in January 2017. Three sampling station were positioned in each stream. Winongo stream $\left(110^{0} 21^{\prime} 055^{\prime}\right.$ ' BT - $7^{0} 45^{\prime}$ 577” LS) (110 21' 162" BT - $7^{0} 47^{\prime}$ 395” LS) (110 21' 057” BT - $7^{0} 49^{\prime}$ 024” LS), Code stream $\left(110^{0} 22^{\prime}\right.$ 231” BT - $\left.7^{0} 46^{\prime} 703^{\prime \prime} \mathrm{LS}\right)\left(110^{0} 22^{\prime} 133^{\prime \prime} \mathrm{BT}-7^{0}\right.$ 47’ 485” LS) (110 22' 270” BT - $7^{0} 48^{\prime}$ '233” LS), and Gajahwong stream $\left(110^{0} 23^{\prime} 805^{\prime \prime}\right.$ BT - $7^{0} 46^{\prime}$ 960” LS) $\left(110^{0} 23^{\prime} 573 ”\right.$ BT - $7^{0} 48$ ' 103” LS $)$ (110 23' 368” BT - $7^{0}$ 48' 349” LS). At each station, physic-chemical parameter were measured. They are: air and soil temperature measured using thermometer, air relative humidity measured using hygrometer, soil $\mathrm{pH}$ and relative humidity using soil tester, and light intensity using lux meter. Concentration of $\mathrm{NO}_{3}{ }^{-}$dan $\mathrm{PO}_{4}{ }^{3-}$ in water and soil were measured by following method. Water sample measured in Balai Laboratorium Kesehatan Yogyakarta, and soil sample in Soil Laboratory, Universitas Gadjah Mada. Vegetation parameter such as growth-form, density, number of species and canopy width were measured by quadrant methods. Samples were taken in square plot size 2 x $0,5 \mathrm{~m}^{2}$ with 10 replications for each station. Unidentified species were preserved, later will be identified in Laboratory Ecology and conservation, Universitas Gadjah Mada refering to identification book of vegetation from Backer (1973) dan Steenis (2006).

\section{RESULTS AND DISCUSSION}

\section{Number of Species and Individu}

Results shown there were 7 growth-forms of riparian vegetation found in all sampling sites. In Winongo there were all 7 growth-forms found but they were distributed unevenly. While in Code, Bamboo and Fern were absent, and in Gajahwong only Fern is absent. Overall, there were 63 species in three streams. Winongo had the highest number of species, there were 63 species, Gajahwong had 53 species, while Code only had 43 species. 


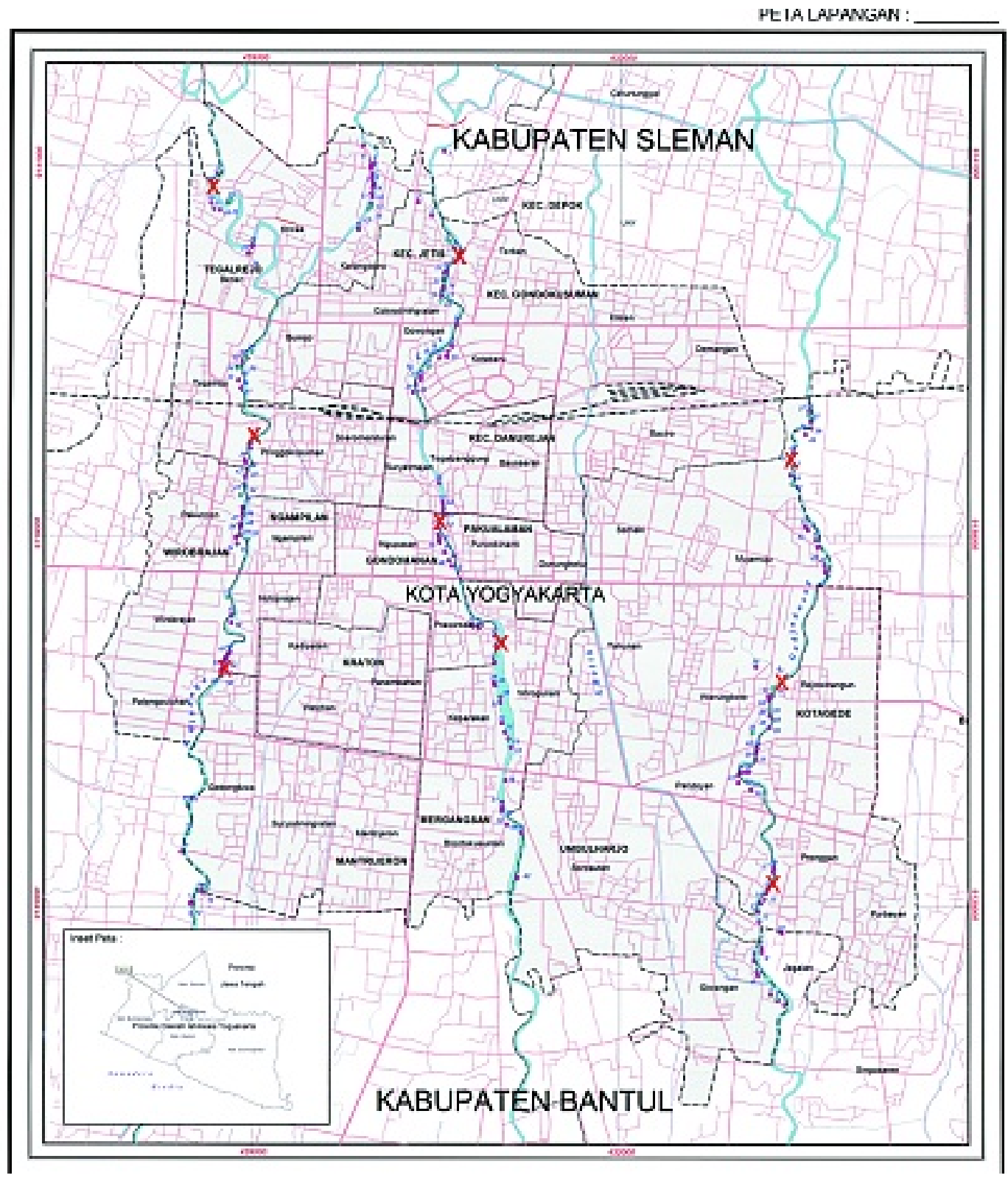

Figure 1. Study sites of Winongo, Code, and Gajahwong Streamn in Yogyakarta. Cross signs show study site.
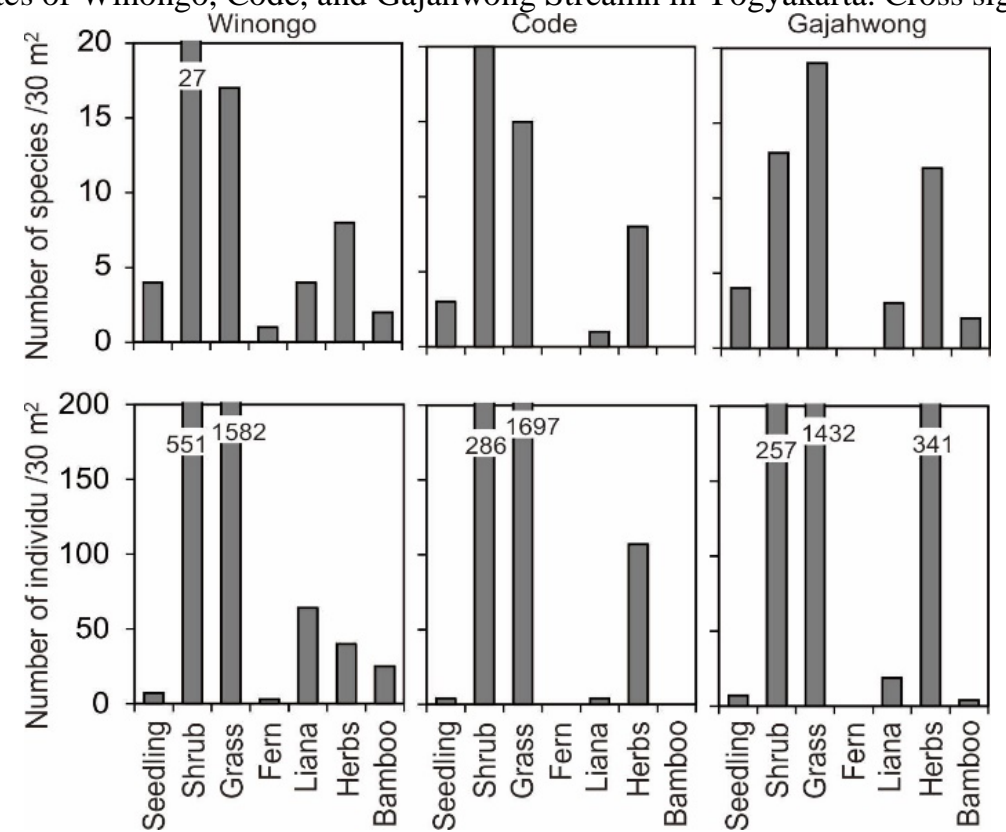

Figure 2. Number of riparian vegetation species and individu in Winongo, Code, and Gajahwong stream. 
Winongo

Code

Gajahwong
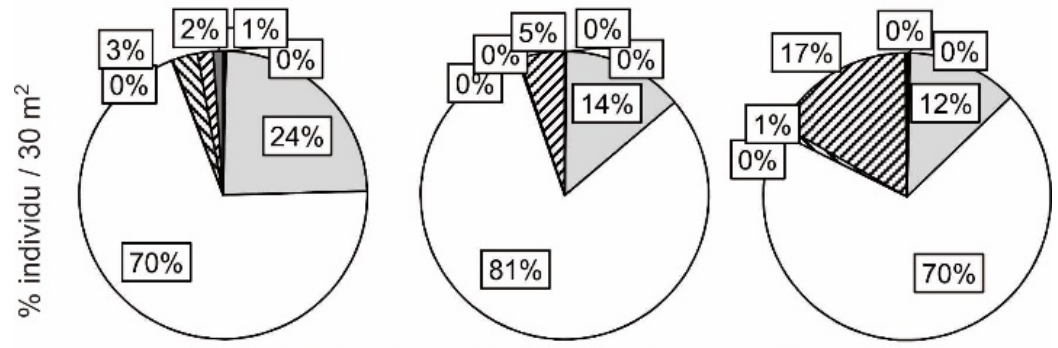

Seedling

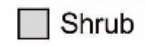

Grass

Fern

N Liana

ש Herbs

Bamboo

Figure 3. Percentage of riparian vegetation densities in Winongo, Code, and Gajahwong streams.

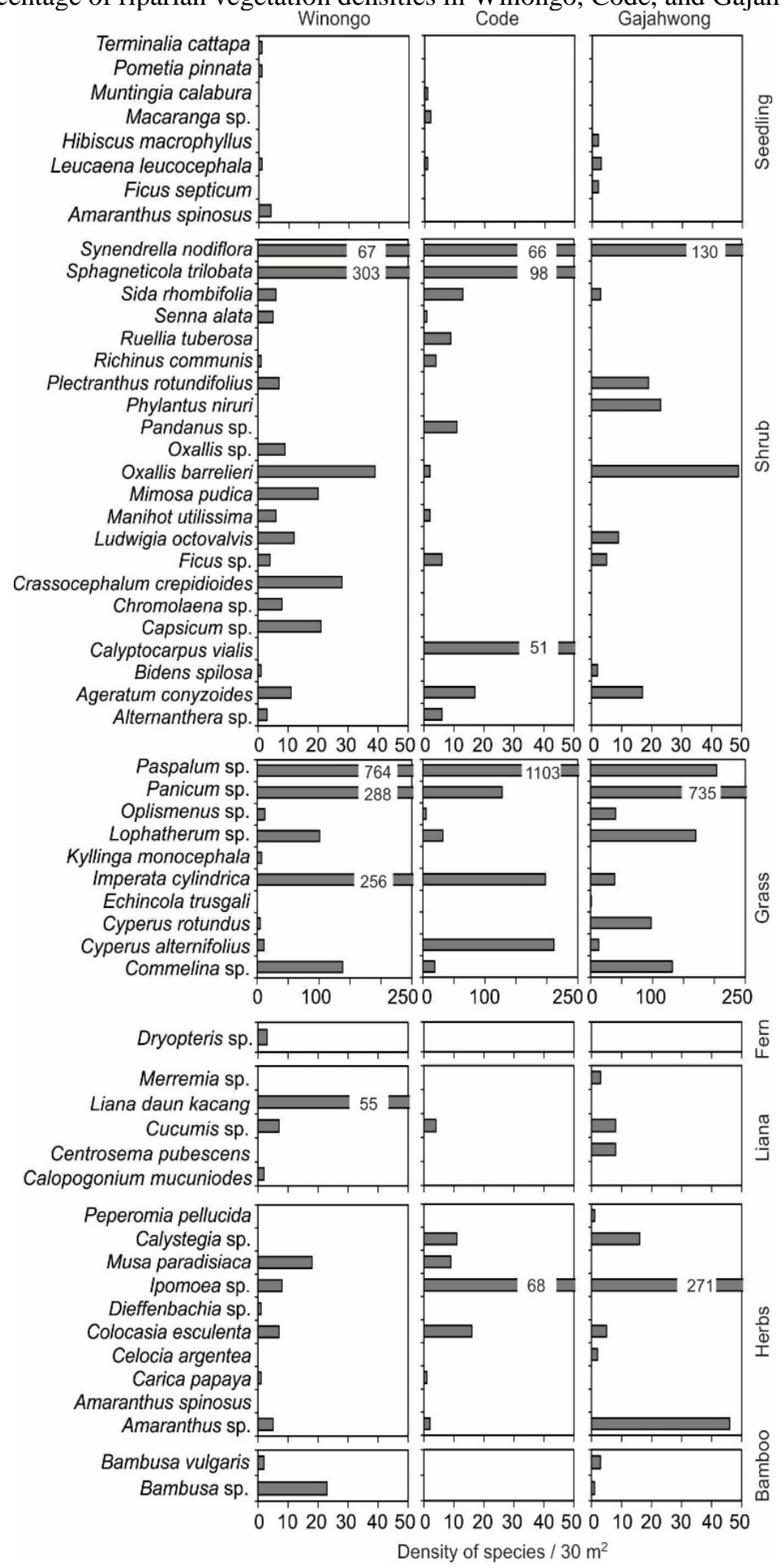

Figure 4. Riparian vegetation densities in Winongo, Code, and Gajahwong streams. 
Riparian vegetation most abundant were in Winongo, there were 2272 ind $30 \mathrm{~m}^{2}$, Code had $2098 \mathrm{ind} / 30 \mathrm{~m}^{2}$, and there were $2060 \mathrm{ind} / 30 \mathrm{~m}^{2}$ in Gajahwong (Figure 2).

Winongo had the highest species number of riparian vegetation, followed by Gajahwong. The lowest species number were in Code. Shrubs were distributed in all part of the streams, their species number were 13-27 species. Followed by grass $15-$ 19 species, and herbs 8-12 species. Although Shrubs had the highest species number, their densities were not higher than grass. Grass densities were $1432-1697 \mathrm{ind} / 30 \mathrm{~m}^{2}$, or $70-81 \%$ from total riparian vegetation found in each sampling site (Figure 2 and 3).

\section{Growth-form Grass}

Grasses were the most abundant growth-form found in each sampling site. Grasses were most abundant in Code streams, there were 1697 ind $/ 30 \mathrm{~m}^{2}$ or $81 \%$ from total density in Code. While in Winongo there were 1582 ind $/ 30 \mathrm{~m}^{2}$ or $70 \%$ from total density and in Gajahwong there were 1432 ind $/ 30 \mathrm{~m}^{2}$ or $70 \%$ from total riparian vegetation found in Gajahwong (Figure 2 and 3). Although total riparian vegetation found in Code lesser than in Winongo, grasses were most abundant in Code.

\section{Riparian Vegetation Species Density}

Species density in studied streams responded to environment conditions. In responds, the three studied streams had almost similar species density although there were some differences. Paspalum sp. were the most distributed species, it can be found in all sampling sites (Figure 4). Paspalum sp. density in Winongo were 764 ind $/ 30 \mathrm{~m}^{2}$ or $33,63 \%$ of all total density, in Code were 1103 ind $/ 30 \mathrm{~m}^{2}$ or $52,57 \%$. While in Gajahwong there were 735 ind/ $30 \mathrm{~m}^{2}$ or $35,68 \%$ of all total density (Figure 4 ).

\section{Nutrient Concentration in Soil and Water}

Nutrient concentration in soil and streams water play the main role in regulating riparian vegetation distribution and abundance. Nitrogen and phospate availability in soil were measured in each sampling site. They were 20,73 and 8,14 (ppm) in Winongo, while in Code were 34,46 and 8,29 (ppm), and in Gajahwong were 27,60 and 8,22 (ppm). While N \& P available in water were 0,26 and 0,6 mg/l in Winongo, Code 0,25 and 0,65 mg/l, also in Gajahwong were 0,53 dan $0,63 \mathrm{mg} / \mathrm{L}$ (Figure 5). Results shown that the availability of $\mathrm{N}$ in soil were relatively higher than $\mathrm{P}$ availability. Meanwhile in stream water, $\mathrm{N}$ availability were lesser than $\mathrm{P}$ available. Each sampling station showed different trend of $\mathrm{N}$ and $\mathrm{P}$ availability concentrations. Nutrient concentrations tend to decreased in station 3 than in station 2 .

\section{Influence of Nitrate and Phosphate on the Riparian vegetation}

Riparian vegetation in Code, Winongo, and Gajahwong showed strong responds to nutrient availability. In each stream both $\mathrm{N}$ and $\mathrm{P}$ available in soil were high, thus riparian vegetation density were high in those three streams. Nutrients availability seems affected by the streams watershed and plants uptake (Figure 5). The most abundant growth-form was grasses. Grass had the ability to fixed nitrogen in poor nutrient condition.
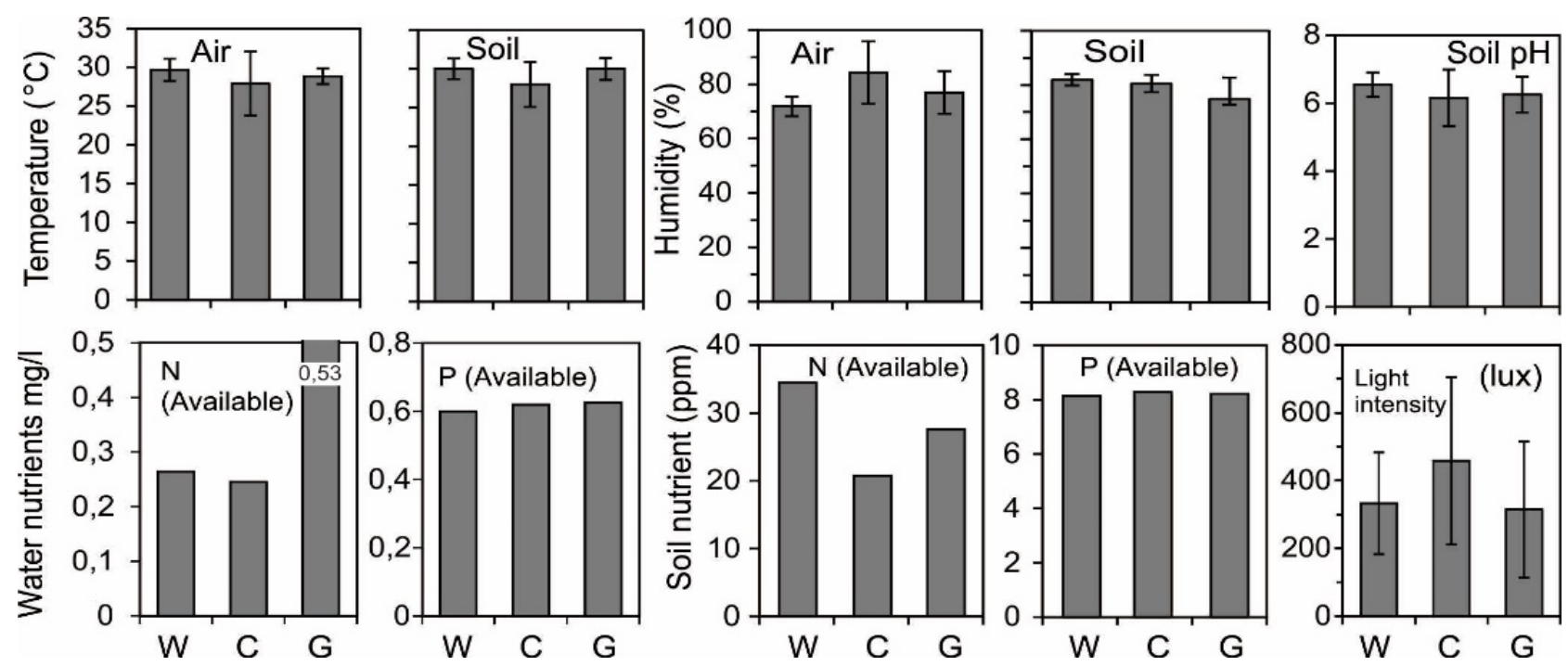

Figure 5. Physic-chemical condition of Winongo, Code and Gajahwong Stream, Yogyakarta. $\mathrm{W}=$ Winongo; $\mathrm{C}=$ Code; $\mathrm{G}=$ Gajahwong. 

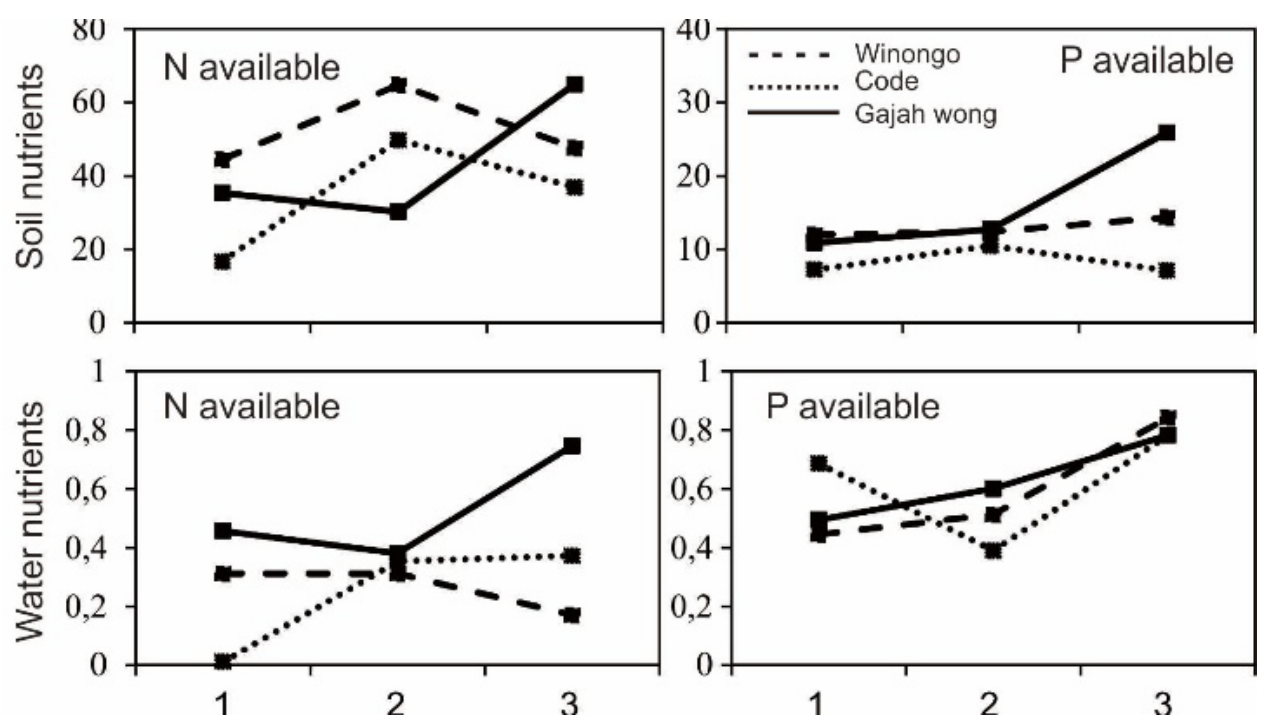

Figure 6. $\mathrm{N}$ and $\mathrm{P}$ concentration in soil and stream water of Winongo, Code, and Gajahwong.

But in these three streams, soil nutrient were very high, thus followed by high density of grass. They were dominating all riparian banks in each sampling site (Figure 6). Data shown that grass density depends on $\mathrm{N}$ availability, their density will rise when $\mathrm{N}$ concentrations were high. These results shown that grass were nutrient greedy. Paspalum sp. and Panicum sp. have the highest densities among other grass species. Paspalum sp. and Panicum sp. were both invasive species. Their reproductive characteristic is an advantage for them in dominating riparian zone (Burton \& Samuelson 2008). We found no higher trees due to narrow riparian bank. Riparian banks in three stream of Yogyakarta can't support tree's growth.

Grass were following nutrient trend except in Code station 3, $\mathrm{N}$ available were decreasing from station 2 but grass densities were rising. This was probably because shrubs densities were declining in this sampling site. Grass and shrubs shown strong competition in all sampling sites. Both growthforms are known for the high demand of nutrient for their growth. Shrubs are annual vegetation, their roots are longer and penetrate deeper in soil than grass. When shrubs are absent, grass start to dominate pressing other growth-form densities as their growth are sporadic covering the soil in short time. Grass domination is contributing to reduced species richness and community structure of riparian vegetation.

Nutrients in soil were higher than in water. Soil tends to keep nutrient with the complex bond between roots and other minerals. While in water, nutrients are flowing by water current (Allan 2004). This research was conducted when heavy rain were showering city of Yogyakarta for three days. This was probably best explain the low concentration of nutrients available in water. In these three streams, we found that $\mathrm{N}$ availability in water has lower concentration than the availability of $\mathrm{P}$ concentration. Phosphate is usually available in a smaller amount than nitrogen. This event was shown that all three streams receiving high input of organic wastes, probably from domestic and agriculture. Human use of detergent and fertilizer donate huge amount of Phosphate to nearest water systems. Result also shown that in each sampling site, the presence of seedling can reduce $\mathrm{N} \& \mathrm{P}$ available in soil. In Gajahwong, nutrient were low when seedling density increased in site 2 , and rising when seedling was absent. The same trend showed in Code and Winongo. This was probably because seedling take up nutrient and save it in their biomass unlike grasses. Seedling and higher plant taxa like shrubs can hold nutrient while floor riparian vegetation hold minimum amount of nutrient (Behren et al. 2014). The absence of seedling in site 3 of Gajahwong probably because the sediment were mostly mud. Seedling needs a good grip for their roots to grow.

Winongo has the highest nutrient concentrations in soil among other streams. Some part of Winongo watersheds are used for agriculture. Phosphate is the limiting factor for vegetation growth, and usually found in a very small amount. Meanwhile in Winongo $\mathrm{P}$ availability were relatively high that indicates high input from fertilizers and domestic waste. Riparian vegetation respond to high nutrient concentrations by large density in each sampling site. Although riparian vegetation densities were high in Winongo, number of species were also high. Riparian vegetation species richness were the highest in Winongo than other two streams. Winongo's riparian zone relatively cleaner than the other two streams. Sediments were mostly gravel in site 1 and partly muddy in site 3 . This condition can support different kind of species than whole mud sediments 
like Code and Gajahwong. Riparian zone of Code were mostly embankment due to rapid construction of human residence. Building up stream embankment only left a small part of riparian zone. This wall reduced water-sediment interface which is very important for stream's health. The absence of this interface left streams with no ability to hold sedimentation also eliminating nutrient concentration reduction. Riparian vegetation composition play role in decreasing nutrient flowed to river water. This will lead to stream shallowing and flood when water debit are high. Code also has the lowest species richness compared to Winongo and Gajahwong. On site 3 of Gajahwong there were rising of nutrient concentrations followed by increasing of grass density. Grass domination causing decrease of species richness in this stream site. The huge amount of nutrients were predicted come from zoo waste and factory waste not far from sampling site. These waste also supplied high amount of sediments into the stream.

\section{CONCLUSIONS}

Riparian zone in City of Yogyakarta streams were high of nutrient. High nutrient concentration decreased riparian vegetation species richness. Grass quickly respond to nutrient concentration changes. Riparian zone condition play the main role in determining stream's health.

\section{DAFTAR PUSTAKA}

Allan, J. D. 2004. Landscapes and Riverscapes: The Influence of Land Use on Streams Ecosystem. Ann. Rev. Ecol. Evol. Sys 35: 257-284.

Backer, C. A. 1973. Atlas of 220 Weeds of Sugar Cane Fields in Java. Indonesian - Sugar Eksperiment Station. Pasuruan.

Behren, C., A. Dietrich, and J. A. Yeakley. 2013. Riparian Vegetation Assemblages and
Associated Landscape Factors Across An Urbanizing Metropolitan Area. Ecoscience 20(4): 373-382.

Burton, M. L., and L. J. Sammuelson. 2008. Influence of Urbanization on Riparian Forest Diversity and Structure in the Georgia Piedmont, US. Plant Ecology 195: 99-115.

Clement, F., J. Ruiz, M. A. Rodriguez, D. Blais, and S. Campeau. 2017. Landscape Diversity and Forest Edge Density Regulate Stream Water Quality in Agricultural Catchments. Ecological indicators 72: 627-639.

Connolly, N. M., R. G., Pearson, and B. A. Pearson, 2016. Riparian Vegetation and Sediment Gradients Determine Invertebrate Diversity In Streams Draining An Agricultural Landscape. Agriculture, Ecosystems and Environment 221: 163-173.

Haycock, N. E., and G. Pinay. 1993. Groundwater Nitrate Dynamics in Grass and Poplar Vegetated Riparian Buffer Strips During The Winter. Journal of Environmental Quality 22 (2): 273-278.

Harding, J.S., K. Claassen, and N. Evers. 2006. Can Forest Fragments Reset Physical and Water Quality Conditions in Agricultural Catchments and Act As Refugia For Forest Stream Invertebrates. Hydrobiologia 568: 391-402.

Gregory, S. V., F. J. Swanson, W. Arthur, and K. W. Cummins. 1991. An Ecosystem Presprective of Riparian Zones. BioScience 41(8):540-551.

Sabater, F., A. Butturini, E. Mart, I. Munoz, A. Romani, J. Wray, and S. Sabater. 2000. Effects of Riparian Vegetation Removal on Nutrient Retention in A Mediterranian Stream. J. N. Am. Benthol. Soc 19(4): 609-620.

Steenis, C. G. G. J. 2006. Flora Pegunungan Jawa. LIPI. Bogor. 